\title{
The Anticedents of Local Government Financial Report Quality
}

\author{
Mega Metalia ${ }^{1}$, Srihadi Winarningsih ${ }^{2}$, Harry Suharman ${ }^{3}$, Hamzah Ritchi $^{4}$, Sari Indah Oktanti \\ Sembiring 5 \\ \{mega.metalia@feb.unila.ac.id ${ }^{1}$, srihadi.winarningsih@fe.unpad.ac.id $^{2}$, \\ $\underline{\text { harry.suharman@fe.unpad.ac.id }}$, $\underline{\text { hamzahritchi@gmail.com }}$, sariindahoktanti@yahoo.co.id $\left.^{5}\right\}$ \\ FEB Universitas Lampung \& FEB Universitas Padjadjaran ${ }^{1}$, FEB Universitas Padjadjaran ${ }^{2}$, FEB \\ Universitas Padjadjaran ${ }^{3}$, Universitas Padjadjaran ${ }^{4}$, FEB Universitas Lampung ${ }^{5}$
}

\begin{abstract}
This study aims to examine how human resource competencies, mastery of information technology, organizational commitment and the application of internal control affect the quality of financial reports of local governments. This research was conducted at the Regional Government in Sumatra, Banten, DKI Jakarta and West Java. Total observations of 199 local governments. The analysis technique used in this research is Structural Equation Model-SEM based on Linear Structural Relationship-LISREL. The results showed that with a significance level of 5\% human resource competency, mastery of information technology, organizational commitment and the application of internal control have a significant and positive effect on the quality of financial statements.
\end{abstract}

Keywords: Human Resource Competency, Mastery Of Information Technology, Organizational Commitment, Application Of Internal Control, Financial Statement Quality

\section{Introduction}

In achieving better governance, the Indonesian government has reformed the management of state finances both at the central and regional governments. Accountability can be interpreted as a form of obligation to account for the success or failure of the implementation of the mission of the organization in achieving the goals and targets that have been set previously, through a media of accountability that is carried out periodically [1].

The Minister of Administrative Reform and Bureaucratic Reform Asman Abnur in [2] revealed that the majority of Local Governments (Pemda) still have below standard accountability values, namely below $\mathrm{B}$, this is because there are still many programs that have not followed the principle of performance based on budgeting, development that is not yet on target, programs and activities are not in accordance with reality, and also does not rule out the possibility of many entrusted projects, this causes waste of state finances so that accountable, effective and efficient of government governance cannot be achieved.

The financial statements are the end result of the accounting process that has been carried out. The financial statements prepared must meet the principles stated in Government Regulation Number 71 Year 2010. Government financial reports are produced from each Regional Work Unit (SKPD) which is then used as the basis for making government financial reports. From the results of the BPK examination and the discovery of findings that are not appropriate and have not been followed up by 15.437 local recommendations (72.1\%), it can be said that the quality of the financial statements of the local government is included in the category of unreliable because there are still irregularities was found by the BPK so that the financial statements are not reliable. 
The phenomenon of low competence is that around 95 percent of the total 4.7 million Civil Servants (PNS) in Indonesia do not have competencies in their fields. This means that civil servants who have competence in their fields are still small, only around 5 percent of the 4.7 million civil servants. Local government financial reports are very useful information for its users, to produce good quality information, an organization must have a good information system. The information system aims to produce financial information. In reality among the Civil Servants (PNS) are still minimal in the mastery of information technology.

Organizational commitment is built on the belief of workers on organizational values, the willingness of workers to help realize the goals of the organization and loyalty to remain a member of the organization. In Government Regulation Number 60 Year 2008 concerning Government Internal Control System (SPIP) related to financial statements is a process designed to provide adequate confidence in the reliability of financial statements in accordance with SAP, which will produce financial statements that have information value. SPI weakness problems generally occurs because the responsible officials / implementers do not / have not recorded accurately, lack of clear policies and accounting treatment, lack of careful planning, do not coordinate with related parties, and are weak in supervision or control. The concept of internal control that has been implemented so far has not been effective or unable to prevent and detect fraud. Another possibility is that internal controls that have not been able to provide reliable financial information for users of financial statements or the concept of internal control have begun to be abandoned so that many violations occur.

\section{Literature Review, Research Framework, and Hypothesis}

\subsection{Literature Review}

Human Resources Competency is to explain what people do at work at various levels and specify the standards of each level, identify characteristics, knowledge and skills needed by individuals that enable them to carry out their duties and responsibilities effectively so as to achieve professional quality standards at work, are as follows: Integrity, leadership, planning and organizing, collaboration and flexibility.

Information technology is a means that is provided by the organization to the maximum in assisting the completion of various tasks and is used as much as possible so as to provide appropriate and effective and efficient benefits. Measurement of the mastery of information technology based on individual behavior from Theory of Planned Behavior (TPB) theory is as follows: background, behavioral beliefs, normative beliefs, subjective norms, belief that a behavior can be implemented and perception of ability to control.

Organizational commitment is something that has been determined through a behavior or attitude approach where through a behavioral approach sees commitment as a unit that is interdependent between organizations and their personal behavior. The measurement of organizational commitment is based on [3] are as follows: affective commitment, normative commitment and ongoing commitment.

Internal control is a process, policy and procedure designed to provide adequate confidence to management regarding the achievement of effective and efficient organizational goals, the 
reliability of financial statements and compliance with applicable regulations [4]. The measurement of the application of internal control are as follows: control environment, risk assessment, control activities, information and communication and monitoring.

The quality of financial statements is financial statements prepared to provide relevant, reliable, honest and understandable information about the financial position and all transactions carried out by a reporting entity. The measurement of the quality of financial statements are as follows: relevant, reliable, comparable and understandable.

\subsection{Research Framework and Hypothesis}

\section{a. Human Resource Competency and Financial Report Quality}

Human resource competencies affect the quality of financial statements as expressed by [5] which explains that human resource competencies are the ability of accounting personnel to carry out the tasks and responsibilities given to them with sufficient knowledge, experience and skills. The competent human resources will be able to translate the logic of accounting well. The failure of human resources, especially in the Regional Government in understanding and applying accounting logic will have an impact on the misrepresentation of financial statements and the discrepancy of reports with the standards set by the government (Warsino, 2008). This certainly affects the quality of financial statements.

According to the results of research[6]. Human resource competencies affect the quality of financial statements. So it can be concluded that the hypothesis of the competence of human resources with the quality of financial statements is as follows:

H1: Human resource competence has a positive effect on the quality of financial statements

b. Mastery of Informatio Technology and Financial Report Quality

Mastery of information technology in general affects the quality of financial statements which is financial statements produce a financial report, several determinants to produce quality financial reports are the competence of human resources, information technology, good governance and asset management. The impact of the development of information technology has caused people who previously did not have the means to access information and communicate with the government to become easier and faster. So it can be concluded that the hypothesis of mastery of information technology with the quality of financial statements is as follows:

$\mathrm{H} 2$ : Mastery of information technology has a positive effect on the quality of financial statements

\section{c. $\quad$ Organizational Commitment and Financial Report Quality}

Organizational commitment has a significant effect on the quality of financial statements is that commitment to the organization is considered to reflect the relative strength of identification individuals are involved in the organization: Commitment to the organization is built on the basis of workers 'trust in organizational values, workers' willingness helps to realize the goals of the organization and loyalty to the values of the organization. So it can be concluded that the hypothesis of organizational commitment with the quality of financial statements is as follows:

H3: Organizational commitment has a positive effect on the quality of financial statements

\section{d. Internal Control Implementation and Financial Report Quality}

The internal control system affects the quality of the financial statements. According to

[7] states that the implementation of the internal control system (which consists of the control environment, risk assessment, control activities, information and communication, and 
monitoring) simultaneously influences the quality of the financial statement information, the magnitude of the influence of variables implementation of an internal control system on the quality of financial statement information. As a decision-making tool, reports must have relevant and reliable quality. Relevant means being able to make decisions differently. In order to have relevant report quality, reports must be presented on time, contain information that enables decision makers to make predictions, and provide feedback for monitoring purposes. Meanwhile, being reliable means that decision makers can trust the report. To get reliable quality, the substance of the report must be verified and tested, as well as fair presentation so it does not direct the decision to a particular decision. So it can be concluded that the hypothesis of the application of internal control with the quality of financial statements is as follows:

H4: The application of internal control has a positive effect on the quality of financial statements

\section{Research Methodology}

The objects in this study are the influence of human resource competence, mastery of information technology, commitment to the organization, and the application of internal control, and the quality of financial reports. To examine these objects the authors conducted research on provincial, district and city governments in Sumatra, DKI Jakarta, Banten and West Java. This research is an explanatory research, because it is a research that states what and how far (factors) are expected to influence a variable with the aim of testing the hypothesis.

The target population in this study is the Regional Governments in Sumatra, Banten, DKI Jakarta and West Java. The sample selection technique used in this study is the Simple Random Sampling technique that was performed with the Microsoft Excel program. Simple Random Sampling is a random sample selection technique, and every member in the population has the same opportunity to be chosen. The unit of analysis of this research is the regional governments in Sumatra, DKI Jakarta, Banten and West Java regions. The observation unit in the study is the Office of Financial Management and Regional Assets (DPKAD).

Data analysis was performed by two types of analysis to obtain results that were consistent with the research objectives, namely:

1. Descriptive analysis to explain the characteristics of the variables studied to support problem solving to obtain operational advice.

2. Analysis through structural equation modeling (Structural Equation Model-SEM based on Linear Structural Relationship-LISREL) in order to answer the problem formulation, and answer hypopthesis.

\section{Result \& Discussion}

Based on the results of statistical tests, the influence of Human Resources Competence on the Quality of Financial Statements, in the Summary Table the estimation results of the Path Coefficient and Statistical Tests can be seen that the path coefficient between Human Resources Competence (KSDM) to the Quality of Financial Statements (KLK) is 0.403 with a positive direction. This shows that the better the Competency of Human Resources (KSDM), the Quality of Financial Statements (KLK) will increase. This research supports previous research [6] which states that the better the competency of human resources, 
the quality of financial statements will increase. The results of this study indicate that human resource competencies have an impact on improving the quality of local government financial reports.

The results of statistical tests the second hypothesis tested was the effect of Mastery of Information Technology on the Quality of Financial Statements. In the Summary Table the estimation results of the Path Coefficient and Statistical Tests can be seen that the path coefficient between the Mastery of Information Technology (PTI) to the Quality of Financial Statements (KLK) of 0.189 with a positive direction. This shows that the better the Mastery of Information Technology (PTI), the Quality of Financial Statements (KLK) will increase. This research supports previous research, which states that the better the mastery of information technology, the better the quality financial statements will increase. The results of this study indicate that the mastery of information technology has an impact on improving the quality of local government financial reports.

Statistical tests result of the third hypothesis tested was the effect of Organizational Commitment on the Quality of Financial Statements. In the Summary Table of the estimated results of the Path coefficient and Statistical Test it can be seen that the path coefficient between Organizational Commitment (KO) to the Quality of Financial Statements (KLK) is 0.132 with a positive direction. This shows that the better the Organizational Commitment (KO), the Quality of Financial Statements (KLK) will increase. This study supports previous research, which states that the better organizational commitment, the quality of financial statements will increase. The results of this study indicate that organizational commitment has an impact on improving the quality of local government financial reports.

The results of statistical tests the fourth hypothesis tested was the effect of the Application of Internal Control on the Quality of Financial Statements. In the Summary Table of the estimated results of the Path Coefficient and Statistical Test it can be seen that the path coefficient between the Implementation of Internal Control (PPI) to the Quality of Financial Statements (KLK) is 0.267 in a positive direction. This shows that the better the Implementation of Internal Control (PPI), the Quality of Financial Statements (KLK) will increase. This study supports previous research [7], [8] which states that the better the application of internal control, the quality of financial statements will increase. The results of this study indicate that the application of internal control has an impact on improving the quality of local government financial reports.

\section{Conclussion}

\subsection{Conclussion}

This research empirically proves the influence of human resource competencies, mastery of information technology, organizational commitment and the application of internal controls on the quality of financial reports and their impact on regional financial accountability. From the 4 (four) hypotheses submitted at the beginning of the study, it was found that all 4 (four) hypotheses of the study were accepted, with the following explanation:

a. Human resource competence has a positive effect on the quality of financial statements. This means that the better the competency of human resources (KSDM), the quality of financial statements (KLK) will increase, conversely if the competency of human resources (KSDM) decrease, the quality of financial statements (KLK) will be lower.

b. Mastery of information technology has a positive effect on the quality of financial statements. This means that the better the mastery of information 
technology (PTI), the quality of financial statements (KLK) will increase, on the contrary if the mastery of information technology (PTI) decrease, the quality of financial statements (KLK) will be lower.

c. Organizational commitment has a positive effect on the quality of financial statements. This means that the better the organizational commitment (KO), the quality of financial statements (KLK) will increase, on the contrary if the organizational commitment $(\mathrm{KO})$ is lower, the quality of financial statements (KLK) will decrease.

d. The application of internal control has a positive effect on the quality of financial statements. This means that the better the application of internal control (PPI), the quality of financial statements (KLK) will increase, conversely if the application of internal control (PPI) decrease, the quality of financial statements (KLK) will be lower.

\subsection{Suggestion}

The results of this study provide input to the government, especially local government organizers as follows:

a. The results of this study are expected to provide input for regional government agencies to focus more on the factors that influence organizational commitment such as job characteristics, alternative employment opportunities, personal characters, and treatment of newcomers so that good regional governance and good government are created.

b. The model built in this study must be retested by subsequent researchers with different loci.

c. The use of methodology in this research in the future should consider the combined methods both quantitatively and qualitatively.

d. The future studies should add more variables that could affect financial report quality or to see the affect of financial report quality to regional financial accountability.

e. The sample in this study should be expanded in the future, so that the research conclusions can be generalized more broadly.

\section{References}

[1] Stanbury, Accountability To Citizens In The Westnnster Model Of Government: More Myth ThanReality. Canada: Fraser Institute Digital Publication:, 2003.

[2] S. M. F. A. and S. K. M. Y. b Nur Fitri Dewia, "Factors influencing the information quality of local government financial statement and financial accountability," Manag. Sci. Lett., vol. 9, pp. 1373-1384, 2019.

[3] "Turner_groups at work 2001 Book." pp. 1-48, 2001, [Online]. Available: http://personal.anderson.ucla.edu/policy.area/faculty/fox/gaw00.pdf\%5Cnpapers3://publication/ uuid/E699BB59-3F6A-49B3-B265-730C438FDA00.

[4] O. Committee of Sponsoring Organizations of the Treadway Commission, "Internal control, integrated framework: Executive summary--Framework--Reporting to external parties-Addendum to" Reporting to external parties," May 1994," no. May, 1994.

[5] A. Kharis, "Pengaruh Kualitas Sumber Daya Manusia Terhadap Peaksanaan sistem Pengendalian Internal Terhadap PT.Avia,” J. Ekon. dan Bisnis, 2010.

[6] H. xu, J. Horn Nord, G. Daryl Nord, and B. Lin, "Key issues of accounting information quality management: Australian case studies," Ind. Manag. Data Syst., vol. 103, no. 7, pp. 461-470, 2003, doi: 10.1108/02635570310489160. 
[7] A. Widyaningsih, "Internal Control System on the Quality of Financial Statement Information and Financial Accountability in Primary Schools in Bandung, Indonesia," Res. J. Financ. Account., vol. 7, no. 10, pp. 10-16, 2016.

[8] C. L. Kewo and N. N. Afiah, "Does Quality of Financial Statement Affected by Internal Control System and Internal Audit?,” Int. J. Econ. Financ. Issues, vol. 7, no. 2, pp. 568-573, 2017. 